\title{
A Simplified Protocol for Producing Taq DNA Polymerase in Biology Laboratory
}

\author{
Touraj Farazmandfar ${ }^{1,2}$, Alireza Rafiei ${ }^{{ }^{*}}{ }^{*}$, Seyed Mohammad bagher Hashemi ${ }^{1}$, Reza Valadan ${ }^{1}$, Seyed Mohammd Alavi ${ }^{3}$, Fatemeh \\ Moradian $^{4}$ \\ ${ }^{1}$ Molecular and Cell Biology Research Center, Faculty of Medicine, Mazandaran University of Medical Sciences, Sari, Iran. \\ ${ }^{2}$ Faculty of Advanced Medical Science Technologies, Golestan University of Medical Sciences, Gorgan, Iran. \\ ${ }^{3}$ Genetics and Agriculture Biotechnology Institue of Tabarestan, Sari Agricultural Sciences and Natural Resources University, Sari, Iran. \\ ${ }^{4}$ Department Basic Sciences, Sari Agricultural Sciences and Natural Resources University, Sari, Iran.
}

Received: 15 Apr 2013

Revised : 25 May2013

Accepted: 26 Sep 2013

Corresponding Author:

Alireza Rafiei

Molecular and Cell Biology Research

Center, Department of Immunology,

Faculty of Medicine, KM 17 Khazarabad

Road, Khazar Sq, Sari, Iran.

Phone:+98-113543614

E-mail:Rafiei1710@gmail.com

\begin{abstract}
Background: $T a q$ DNA polymerase is a very important enzyme for molecular biological studies such as DNA amplification and DNA sequencing by the PCR. It is a standard enzyme that is used in $90 \%$ of molecular biology labs today. The aim of this study was to produce Taq DNA polymerase enzyme in $E$. coli by a reliable, practical, simple and low cost method.

Materials and Methods: In this study, the Taq gene was amplified from the genomic DNA of Thermus aquaticus and cloned into pTrc99A vector. Recombinant plasmid is expressed in E. coli strain TOP10. Product protein is extracted and purified. Expression of gene was analyzed by SDS-PAGE and gene amplification.

Results: In SDS-PAGE, bands were observed in the range of $94 \mathrm{KDa}$. The density of protein bands in agarose gel electrophoresis indicated that the purified enzyme is more active than the nonpurified one.

Conclusion: The protocols described in this paper lead to the production of pure and active enzyme that can be applied in both teaching and research laboratories.
\end{abstract}

Keywords: Taq polymerase; Expression; Purification

Please cite this article as: Farazmandfar T, Rafiei A, Hashemi SMB, Valadan R, Alavi SM, Moradian F. A Simplified Protocol for Producing Taq DNA Polymerase in Biology Laboratory. Res Mol Med. 2013; 1 (2): 23-26

\section{Introduction}

The polymerase chain reaction (PCR) and DNA sequencing are usually used techniques of molecular biology which utilize DNA polymerases. The high temperatures required for DNA amplification in PCR entail a thermo stable enzyme, and Taq DNA polymerase obtained from a heat stable bacterium called Thermus aquaticus has solved this problem. The high optimal polymerization temperature of this enzyme also makes it useful tools for sequencing of DNA (1).

Taq DNA Polymerase has a molecular weight of about 66-94 kilo Daltons (kDa). The full length 94 $\mathrm{kDa}$ of Taq polymerase has the highest activity and half-life of 10 minutes at $97^{\circ} \mathrm{C} \mathrm{(2).} \mathrm{Taq} \mathrm{polymerase}$ catalyzes the incorporation of dNTPs into DNA with the rate of about a thousand base pairs per minute. It requires a DNA template, a primer and the divalent cation magnesium. Taq polymerase contains a 5'-3' exonuclease activity. It does not have a $3^{\prime}-5^{\prime}$ exonuclease activity and thus, no proof reading function (3). Taq DNA polymerase has a terminal transferase activity.

It adds an adenine at $3^{\prime}$ end found to be useful to produce TA cloning plasmids which possess a $3^{\prime}$ thymine overhangs. This allows ligation using DNA ligase be quickly be accomplished with the adenine overhangs of the PCR product (4). However, the Taq DNA polymerase isolated from Thermus aquaticus was the first characterized thermo stable enzyme but until now, the more than fifteen DNA polymerase genes have been cloned and sequenced from various organisms by PCR cloning technique. The recombinant 
Taq DNA polymerase expressed in E. coli represents the identical characteristics to native $T a q$ from Thermus aquaticus with preservation of activity, specificity and thermo stability in PCR.

However, the lac promoter and its derivatives like ptac are frequently applied in order to control gene expression, and almost in most cases, Isopropyl $\beta$-D1-thiogalactopyranoside (IPTG) is used as inducer for foreign gene expression (4). In this study, we describe a reliable, practical, simple and low cost method to produce the enzyme of Taq DNA polymerase in the E. coli for use in PCR, in any molecular laboratory.

\section{Materials and Methods \\ PCR and Cloning}

The Genomic DNA of Thermus aquaticus strain YT1 (ATCC-25104) was isolated using high pure PCR template preparation kit (Roche, Germany). A pair of primers was designed based on the $5^{\prime}$ and $3^{\prime}$ ends of the DNA sequence of Taq DNA polymerase gene (Accession No. DD137468) and were used for PCR amplification. A $2.5 \mathrm{~Kb}$ fragment was amplified by primers of forward, 5'-CGGAATTCTGAGGAGGTAACATGAGGG-3' and reverse, 5'-CGTCGACTAGATCACTCCTTGGCGGAGAG -3' which created unique EcoRI and SalI restriction sites (underlined), respectively, at each end of the amplified DNA fragment. PCR amplification was performed using the following reagents: PCR reaction buffer $(50 \mathrm{mM}$ $\mathrm{KCl}, 20 \mathrm{mM}$ Tris- $\mathrm{HCl}(\mathrm{pH}=8.3), 1 \mu \mathrm{M}$ each of primer, $1.5 \mathrm{mM} \mathrm{MgCl} 2,250 \mu \mathrm{M}$ dNTPs, $30 \mathrm{ng}$ template DNA, 2 Unit Pfu DNA polymeras (Fermentas, Germany). The final reaction volume was $30 \mu \mathrm{l}$. Thermocycling conditions were $95{ }^{\circ} \mathrm{C}$ initial denaturing for 4 minutes followed by 30 cycles of 94 ${ }^{\circ} \mathrm{C}$ denaturing for 30 seconds, annealing at $55^{\circ} \mathrm{C}$ for 2 minutes, and extension at $68^{\circ} \mathrm{C}$ for 2 minutes; and the last final extension at $68{ }^{\circ} \mathrm{C}$ for 10 minutes. Amplified products were analyzed by electrophoresis using $1 \%$ agarose gels. DNA fragments from agarose gels were extracted by an Agarose Gel DNA Extraction Kit (Roche, Germany). The fragment was ligated into the expression vector of pTrc99A (Addgene) that had been digested before with EcoRI and SalI (Fermentas, Germany) using Rapid DNA Ligation Kit (Roche, Germany). Ligate was transformed into competent $E$. coli strain, TOP 10 (Invitrogene) by $\mathrm{CaCl} 2$ (Sigma, Germany) using heat shock method at $42{ }^{\circ} \mathrm{C}$ for 45 seconds. These mixtures were then plated on Lauria Bertaini (LB) agar media (Merck, Germany) containing $100 \mu \mathrm{g} / \mathrm{ml}$ ampicillin and incubated at $37{ }^{\circ} \mathrm{C}$ overnight. The obtained colonies were grown in $2 \mathrm{ml} \mathrm{LB}$ broth media (Merck, Germany) containing $100 \mu \mathrm{g} / \mathrm{ml}$ ampicillin at $37{ }^{\circ} \mathrm{C}$ with shaking at $200 \mathrm{rpm}$. The recombinant plasmids prepared by a Qiagen mini-prep kit and the presence of the amplicon had been confirmed by sequencing. Expression and Extraction

The recombinant $E$. coli was cultured in $200 \mathrm{ml}$ of LB broth overnight at $37{ }^{\circ} \mathrm{C}$ containing $100 \mu \mathrm{g} / \mathrm{ml}$ ampicillin. The expression of recombinant protein was induced by $0.125 \mathrm{mg} / \mathrm{ml}$ IPTG (Sigma, Germany) until the bacteria reach OD600 of approximately 0.7 .

The culture was continued overnight. No addition of inducer was used as negative control. The bacteria were harvested by centrifuging in $6000 \mathrm{rpm}$ for 15 minutes at $4{ }^{\circ} \mathrm{C}$ and washed in $100 \mathrm{ml}$ of sterilized $\mathrm{A}$ Buffer [50 mM Tris-HCl pH=7.8, $50 \mathrm{mM}$ Dextrose, 1 mM EDTA (Merck, Germany)]. The cells were spin down and resuspend in $2 \mathrm{ml}$ of A Buffer and $4 \mathrm{mg} / \mathrm{ml}$ lysozyme (Sigma, Germany) for 15 minutes at room temperature (RT). The bacteria were then lysed by adding $2 \mathrm{ml}$ of sterilized lysis buffer [50 mM TrisHCI $\mathrm{pH}=7.8,50 \mathrm{mM} \mathrm{KCI}, 1 \mathrm{mM}$ EDTA $\mathrm{pH}=7.8,1 \%$ Triton x-100 (Merck, Germany)] and incubated in 15 $\mathrm{ml}$ falcon tube at $70{ }^{\circ} \mathrm{C}$ for 1 hour. The lysis mixture was then centrifuged at $14000 \mathrm{rpm}$ for 10 minutes at $4{ }^{\circ} \mathrm{C}$, and the clarified supernatant was transferred to a sterile $15 \mathrm{ml}$ falcon tube.

The enzyme was recovered from the clarified supernatant by adding 1 gram of Ammonium sulphate (Merck, Germany) while stirring rapidly for 10 minutes at RT. The solution was then centrifuged at $14000 \mathrm{rpm}$ for 10 minutes and protein precipitate was collected (pellets and surface). The pellet was resuspended in $3 \mathrm{ml}$ of A buffer and dialyzed against $25 \mathrm{ml}$ sterilized storage buffer $[20 \mathrm{mM}$ Tris-HCI $\mathrm{pH}=7.8,100 \mathrm{mM} \mathrm{NaCI}, 0.1 \mathrm{mM}$ EDTA $\mathrm{pH}=7.8,1 \%$ Triton $\mathrm{x}-100,50 \%$ glycerol (Merck, Germany)] overnight at $4{ }^{\circ} \mathrm{C}$. The resulting protein was diluted $1: 1$ with storage buffer.

\section{Enzyme assay}

The expression of Taq DNA polymerase was analyzed by SDS-polyacrylamide gel electrophoresis (SDS-PAGE) (1). The activity of the enzyme was determined using a PCR amplification reaction with titration against a commercial Taq DNA polymerase (Fermentas, Germany).

Human genomic DNA was used as template for amplifying a 470 base paired fragment. To obtain the optimum $\mathrm{pH}$ in which the enzyme is stable for a longer time, the storage buffer was prepared in a gradient $\mathrm{pH}$ range 7.2 to 8.2. After two months storage in $-20{ }^{\circ} \mathrm{C}$, the activity of enzyme was assayed by PCR.

\section{Results}

In SDS-PAGE analysis, protein segments were observed in the range of $94 \mathrm{KDa}$ which confirmed that Taq gene was expressed. In this assay, the 
expression levels of Taq protein were measured in three steps; No inducing E. coli with IPTG, induced $E$. coli before dialysis and induced $E$. coli after dialysis.

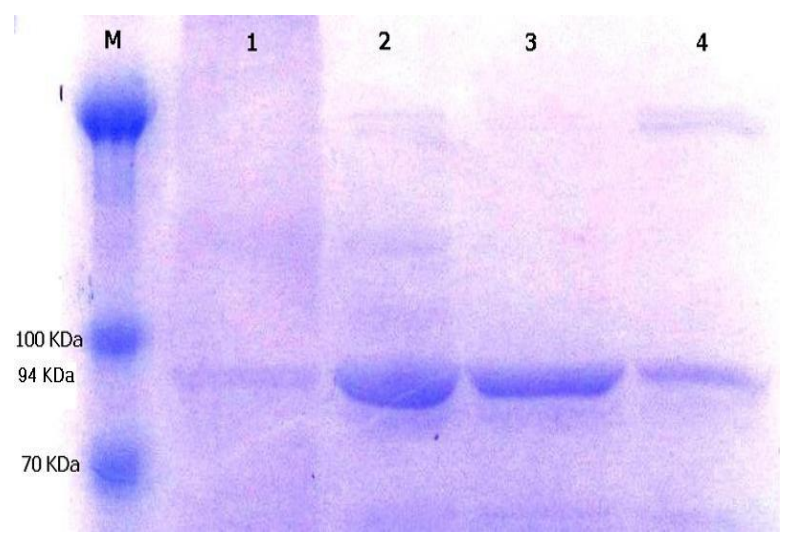

Figure 1. SDS-PAGE analysis of Taq DNA polymerase. $7 \mu 1$ of commercial Taq equal to 5 units (line1). $7 \mu 1$ IPTG induced protein after dialysis (line 2). $7 \mu 1$ IPTG induced before dialysis (line 3). 7 $\mu 1$ non-induced protein after dialysis (line 4 ).

To estimate the enzyme activity, the recombinant enzyme was titrated in five dilutions in both dialyzed and non-dialyzed against a commercial Taq. Bands in agarose gel electrophoresis indicated that the purified enzyme is active (Figure 2). As shown in figure 2, the activity of the non-dialyzed enzyme is less than dialyzed. Assessment of the enzyme activity at different $\mathrm{pH}$ of storage buffer showed that Taq DNA polymerase enzyme has remained active longer at $\mathrm{pH}$ close to 7.8 after a couple of months.

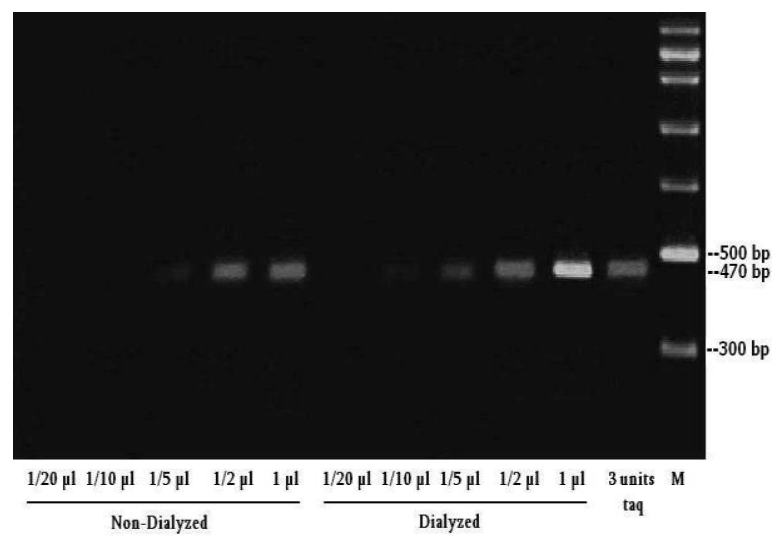

Figure 2. Enzyme activity assay.Comparison of PCR band intensity in dialyzed and non-dialyzed $T a q$ protein at different dilutions.

\section{Discussion}

Taq DNA polymerase is an important enzyme for DNA amplification and sequencing by the PCR in molecular biological studies (5). It is a standard enzyme used in most of molecular biology laboratories today. Despite all the problems associated with culture of T. aquaticus, gene isolation and cloning and also purification of Taq DNA polymerase, maintain the stability of the enzyme for long-term storage is also huge challenge that must be considered. The SDS-PAGE results show that the intensity of expressed Taq protein is close to the Taq protein expressed by some group of molecular scientists $(3,6,7)$. Comparison of the induced and non- induced pattern of protein concentrations in SDS-PAGE shows that trc promoter in ptrc99a plasmid is a powerful promoter in gene expression in E. coli.

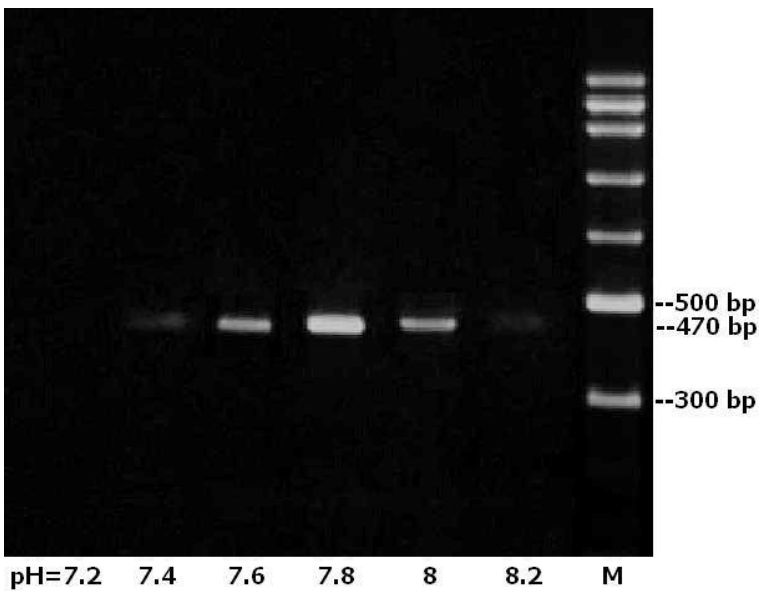

Figure 3. Enzyme stability assay.Comparison of PCR band intensity at different $\mathrm{pH}$ of storage buffer two months after purification.

Nowadays, more patents of Taq DNA polymerase production have recently expired which provide an opportunity for many molecular biology researchers to produce and use their own Taq DNA polymerase. The protocols described in this paper lead to the production of pure and active enzyme that can be applied in both teaching and research laboratories. Taq DNA polymerase was remained active for at least one year.

\section{References}

1. Grimm E, Arbuthnot P. Rapid purification of recombinant Taq DNA polymerase by freezing and high temperature thawing of bacterial expression cultures. Nucleic Acids Res. 1995; 23 (21): 4518-9. PMID: 7501478

2. Mir Mohammad Sadeghi H, Rabbani M, Moazen F. Amplification and cloning of Taq DNA polymerase gene from Thermus Aquaticus strain YT-1. Res Pharm Sci. 2007; 1: 49-52.

3. Roayaei M, Galehdari H. Cloning and Expression of Thermus aquaticus DNA polymerase in Escherichia coli. Jundishapur $\mathbf{J}$ Microbiol. 2008; 1 (1): 1-5.

4. Mishra N, Kumar A. Cloning and characterization of isolated 
Taq DNA polymerase gene from phage. The Bioscan. 2010; 5 (1): 7-11.

5. Sadeghi HMM, Rabbani M, Rismani E, et al. Optimization of the expression of reteplase in Escherichia coli. Res Pharm Sci. 2011; 6 (2): 87-92. PMID: 22224091

6. Pluthero FG. Rapid purification of high-activity Taq DNA polymerase. Nucleic Acids Res. 1993; 21 (20): 4850-4851. PMID: 8233838

7. Ferralli P, Egan JD, Erickson FL. Making Taq DNA polymerase in the undergraduate biology laboratory. Bios. 2007; 78 (2): 69-74.
8. Engelke DR, Krikos A, Bruck ME, Ginsburg D. Purification of Thermus aquaticus DNA polymerase expressed in Escherichia coli. Anal Biochem. 1990; 191: 396-400. PMID: 2085185

9. Lu C, Erickson HP. Expression in Escherichia coli of the thermostable DNA polymerase from Pyrococcus furiosus. Protein Expr Purif. 1997; 11 (2): 179-84. PMID: 9367814

10. Yang Z, Ding Y, Zhang Y, Liu F. Rapid purification of truncated Taq DNA polymerase Stoffel fragment by boiling lysis of bacterial expression cultures. Biotechnol Appl Biochem. 2008; 50 (2): 71-5. PMID: 18184110 